\title{
Diakoniatyöntekijöiden käsityksiä taloudellisen avustustyön asiantuntijuudesta
}

\author{
ELINA JUNTUNEN
}

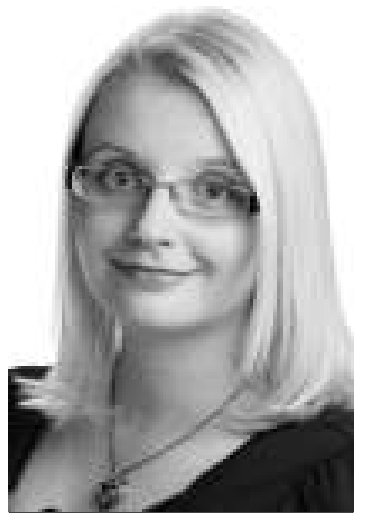

\begin{abstract}
Kirkon diakoniatyö sisälsi vuoden 2007 tilastojen mukaan eniten keskusteluapua ja taloudellista apua. Taloudellista apua sai joka neljäs asiakas. Diakoniatyöntekijät ovat toisinaan kokeneet olevansa taloudellisessa avustustyössä asiantuntijuutensa rajoilla. Taloudelllisen avustamisen asiantuntijuuden analysointi on kirjoittajan näkemyksen mukaan avainasemassa, kun jäsennetään diakoniatyön paikkaa, tehtävää ja erityisyyttä yhteiskunnallisen ja seurakunnallisessa työn konteksteissa.

Artikkelinsa lopussa kirjoittaja pohtii myös diakoniatyöntekijöiden taloudellisen avustustyön ja sosiaalityön asiantuntijuuden keskinäisiä eroja.
\end{abstract}

2000-luvulla evankelis-luterilaisen kirkon diakoniatyö on profiloitunut erityisesti köyhien auttamiseen sekä hyvinvointiyhteiskunnan julkisen tuen täydentäjäksi ja jopa paikkaajaksi (Yeung 2003, 206; 213). Vuonna 2007 diakoniatyö sisälsi eniten keskusteluapua ja taloudellista apua. ${ }^{1}$ Avun piirissä oli noin 193000 suomalaista ja asiakaskontakteja kertyi yli 709 000. Taloudellista apua sai joka neljäs asiakas. (Kääriäinen ym. 2008.) Taloudellinen avustaminen käsitetään usein aineelliseksi auttamiseksi, esimerkiksi laskujen maksamiseksi, ruokakassien tai osto-osoitusten antamiseksi. Paikallisseurakunnat käyttivät aineelliseen apuun vuonna 2007 noin 5,5 miljoonaa euroa ${ }^{2}$ (Kääriäinen ym. 2008). Taloudellisen avustamisen kokonaisuuteen diakoniatyöntekijät itse liittävät myös henkisen ja hengellisen auttamisen. Apuun liittyy huomattavan paljon muun muassa erilaista sosiaalista, taloudellista ja terveydellistä neuvontaa sekä asiakkaan perusoikeuksien ajamista ja henkisen jaksamisen tukemista. (Juntunen 2006.)

Diakoniatyöntekijät ovat kokeneet toimivansa toisinaan monimuotoisessa taloudellisessa avustustyössään asiantuntijuutensa rajoilla. Yhtäältä asiantuntijuuden rajoilla toimimisen on arvioitu tukevan työmotivaation säilymistä ja uusiutumista, mutta toisaalta sen on katsottu heikentävän diakoniatyöntekijän työmotivaatiota ja työssä jaksamista. (Juntunen 2007, 106.)

Taloudellinen avustaminen aiheuttaa jännitteitä yhteiskunnan sosiaalisen työn kentällä sekä evankelis-luterilaisessa kirkossa. ${ }^{3}$ Periaatteelliseksi kysymykseksi herää esimerkiksi se, tuleeko diakoniatyön paikata yhteiskunnan palvelujen puutteita ja miten se tulisi tehdä. Sosiaalityön on katsottu ajautuneen kapealle byrokratiatyön alueelle, jonka vuoksi diakoniatyössä vastataan siihen, mihin sosiaalityössä ei ole mahdollisuuksia (Paajanen 2008, 91). Onko olemassa riski, että diakoniatyö menettää erityisosaamistaan paikatessaan kunnallista sosiaalityötä?

Pohdinta diakoniatyön yhteiskunnallisesta paikasta/paikoista saa myös kysymään, millainen on diakoniatyön paikka suhteessa kirkon ammatteihin ja hengelliseen työhön. Täydentäessään ja paikatessaan julkisia hyvinvointipalveluja diakoniatyön seurakunnallinen ja hengellinen rooli on usein hämärtynyt (Pyykkö 2007, 110). Diakoniatyön taloudellisen avustustyön jännitteinen ja usein epäselvä asema yhteiskunnassa ja kirkossa 
saattaa johtua esimerkiksi siitä, että diakoniatyöhön liittyy vaikeus tiivistää työn kokonaisuutta ja kuvata työssä tarvittavaa osaamista. Tällöin diakoniatyön asiantuntijuutta on helppo kyseenalaistaa. (Vrt. Pohjola 2007, 7-8.)

Diakoniatyön taloudellisen avustamisen asiantuntijuuden analysoiminen on kuitenkin avainasemassa, kun jäsennetään diakoniatyön paikkaa, tehtävää ja erityisyyttä yhteiskunnallisen ja seurakunnallisen työn konteksteissa. Asiantuntijuuden määrittelyyn liittyy aina kysymys asiantuntijuuden osoittamisesta niissä sosiaalisissa yhteyksissä, joissa sitä jaetaan ja otetaan käyttöön (Eteläpelto \& Tynjälä 1999, 20).

Diakoniatyötä koskevissa tutkimuksissa ei aiemmin ole juuri käsitelty taloudelliseen avustustyöhön liittyvää asiantuntijuutta. Suhonen havaitsi tutkimuksessaan diakoniatyöntekijöiden ja pappien hiljaisesta tiedosta, että diakoniatyön hiljainen tieto on oivaltamista ja työmenetelmien asianmukaista soveltamista. Hiljaisen tiedon siirto mahdollistuu vuorovaikutteisesti, sanallisesti ja kirjallisesti, muiden työntekijöiden kanssa. (Suhonen 2009, 122; 149.)

Sosiaali- ja terveysalan ilmiöpohjaista asiantuntijuutta käsittelevä tutkimuskirjallisuus päihdetyön (Aalto-Mattila 2007; Forsseìn 2005) sekä saattohoidon ja terapiatyön (Mäkeläinen \& Mäkeläinen 1999; Howe 1993) asiantuntijuudesta tarjoavat käsitteitä myös diakoniatyön asiantuntijuuden käsittelyyn. Sellaisena toimii esimerkiksi asiakastyön asiantuntijuuteen liittyvä luottamuksen ja luottamustyön merkitys. Diakoniatyön taloudellisen avun asiantuntijuutta lähellä on myös mielenterveystyön asiantuntijuus (Pesonen 2005; Saarelainen ym. 2002) sekä tunnetyön asiantuntijuus (Tikkamäki 2007; Molander 2003). Asiakastyössä esille tulevat niin asiakkaiden tunteet kuin myös työntekijän tunteet ja tunteiden hallinta. Sosiaalityön alueella käsitellyt teemat refleksiivisestä asiantuntijuudesta ovat niin ikään avuksi diakoniatyöntekijöiden asiantuntijuutta tarkasteltaessa (Karvinen 1996; Payne 1996).

Tässä artikkelissa ${ }^{4}$ kysyn, millaisia käsityksiä diakoniatyöntekijöillä on asiantuntijuudestaan yhden keskeisimmän työmuodon eli taloudellisen avustustyön tehtävissä. Koska taloudellisessa avustustyössä on havaittu kunnallista sosiaalityötä täydentävä tai paikkaava rooli, pohdin myös artikkelin lopussa, millaisia eroja on havaittavissa diakoniatyöntekijöiden taloudellisen avustustyön ja sosiaalityön asiantuntijuuden välillä. ${ }^{5}$

\section{Asiantuntijuus}

Diakoniatyön tehtäväkenttä on laaja ja monitasoinen. Kirkkohallitus odottaa diakoniatyöntekijöiden osaamiselta muun muassa hengellisen työn ja diakonisen asiakastyön osaamista, kirkon organisaation tuntemista ja yhteistyötaitoja sekä yhteisöllistä ja yhteiskunnallista osaamista. ${ }^{6}$ (Diakoniatyöntekijöiden ydinosaamiskuvaus 30.3.2007.) Työelämässä vaaditaan entistä enemmän oman asiantuntijuuden tunnistamista ja näkyväksi tekemistä, sillä osaamisen esittämistä ja arviointia koskevia käytäntöjä on otettu vahvasti käyttöön (Eteläpelto \& Vähäsantanen 2006, 27).

Käsitteenä asiantuntijuus soveltuu hyvin diakoniatyön taloudellisen avustustyön tarkasteluun, sillä asiantuntijuus ei rajaudu vain ammatillisen aseman mukaan vaan asian, aiheen, tehtävän tai ongelma-alueen mukaan (Eteläpelto 1996, 21). Asiantuntijuutta määritellään usein tehtäväkeskeiseksi osaamiseksi ja ammattitaidoksi, joiden avulla ymmärretään työn lähtökohtia ja reunaehtoja, saavutetaan työn tavoitteita sekä hallitaan työprosesseja ja työhön vaikuttavia ilmiökokonaisuuksia (Pohjola 2007). Lähestymistapaani diakoniatyöntekijöiden käsityksiin omasta asiantuntijuudestaan ohjaa näkemys kokemuksellisesta asiantuntijuudesta (Isopahkala-Bouret 2005; 2008), sillä tarkastelen niitä asiantuntijuuden osa-alueita, joita diakoniatyöntekijät itse pitävät vahvoina alueinaan ja joihin he luottavat. Kokemukselliseen asiantuntijuuteen sisältyy näkemys asiantuntijuudesta yksilöllisesti ja kollektiivisesti kehittyvänä prosessina. Koska diakoniatyön taloudellinen avustaminen on lähellä sosiaalityön tehtäväkenttää, avaan näkökulmia sosiaalityön asiantuntijuuteen.

Yksilökohtaisesti tarkasteltuna asiantuntijuuden (eksperttiyden) kokeminen koostuu relevantista tiedosta, itseluottamuksesta ja kyvystä toimia (Isopahkala-Bouret 2008, 89-92; 2005, 157158). Asiantuntijuus merkitsee asioiden tuntemista ja tiedonkäsittelykapasiteettia. Siihen liitetään myös kehittyneet tietorakenteet sekä intuitiivinen ja tilannesidonnainen tieto (Isopahkala-Bouret 2005). Ruohotie $(2006,10)$ painottaa asiantuntijuuden määrittelyssä asiantuntijan ammattispesifistä tietoa, taitoa soveltaa tietoa käytännön ongelmiin sekä metakognitiivisia ajattelun taitoja. Asiantuntijuus merkitsee jatkuvaa oppimista yksityis- ja työelämän kokemuksista erityisesti haastavissa ongelmanratkaisutilanteissa (Valkeavaara 1999, 
180). Asiantuntijuus on elämänkerrallisesti kehittyvä prosessi, jossa merkittävä osa asiantuntijuudesta rakentuu arkipäivän kokemuksista ja kehittyy hiljaiseksi tiedoksi, joka jää käsitteellistämisen tai kielellisen tiedon ulkopuolelle (Desforges 1995, 391). Diakoniatyön hiljaisen tiedon siirtäminen uusille työntekijöille mahdollistuu muun muassa työparityöskentelyn kautta (Suhonen 2009, 123).

Ajatus diakoniatyön hiljaisen tiedon siirrettävyydestä perustuu näkemykseen asiantuntijuuden kollektiivisesta luonteesta. Kokemuksellisessa asiantuntijuudessa keskeistä on yksilön luottamus omaan asiantuntijuuteensa, mutta olennaista on, että myös muut luottavat yksilön asiantuntijuuteen (Isopahkala-Bouret 2008, 85; Parviainen 2006, 170-172). Kokemuksellisen asiantuntijuuden näkökulmasta asiantuntijuus rakentuu vuorovaikutteisesti ja yhteisöllisesti erilaissa sosiaalisissa verkostoissa (Isopahkala-Bouret 2008, 85; Mieg 2001, 43). Kollektiivisella asiantuntijuudella tarkoitetaan osaamista yhdessä. Yhdessä osaaminen on "tiedon muodostamista, jakamista, käsittelemistä ja yhdistämistä toisen tai useamman ihmisen kanssa siten, että yksittäiset osaamisalueet ovat enemmän kuin osiensa summa" (Koivunen \& Parviainen 2004). Hanssonin (1998) mukaan kollektiivinen asiantuntijuus muodostuu kolmesta kompetenssista, jotka toteutuvat yksilön toimiessa ryhmän jäsenenä. Ensimmäinen kompetenssi sisältää praktisen asiantuntijuuden, joka tarkoittaa taitoja suorittaa tietyt tehtävät. Toinen kompetenssi sisältää kyvyn vuorovaikutukseen ja yhteistyöhön. Kolmas kompetenssi sisältää myötätunnon, joka tarkoittaa erilaisia sosiaalisia taitoja. (Hansson 1998, 26-29.) Asiantuntijuuden kollektiivinen kompetenssi ilmentää yksilöiden toimintaa verkostoissa, ja verkostojen mahdollisuuksia ratkaista yhdessä uusia ja muuttuvia ongelmia (Valkeavaara 1999).

Sosiaalityön asiantuntijuuteen sisällytetään tieto- ja taitoperusta, eettisyys, paikka- ja tilanneanalyysi sekä ammatillinen näkemyksellisyys (Pohjola 2007, 8-10). Sosiaalityön konteksteissa tarvitaan kykyä toimia muuttuvissa olosuhteissa kriittistä reflektiivisyyttä hyödyntäen (Karvinen 1996, 45). Kuten diakoniatyön, myös sosiaalityön asiantuntijuudessa korostuu monin eri tavoin kollektiivinen asiantuntijuus. Juhila (2006, 137-140) tuo esille sosiaalityön horisontaalisen asiantuntijuuden, jolla hän tarkoittaa sosiaalityöntekijän ja asiakkaan kumppanuutta. Työntekijä ja asiakas toimivat rinnakkain, tasavertaisina kumppaneina, et- sien ratkaisuja ja mahdollisuuksia asiakkaan elämäntilanteeseen. Sosiaalityön asiakastapaukset vaativat paikallistasoista, ainutlaatuista, tilannesidonnaista asiantuntijuutta ja siihen perustuvia ratkaisuja. (Juhila 2006, 137-140.) Myös kirkon diakoniatyössä on viime vuosina vaadittu arkeen, paikallisuuteen ja paikallisyhteisöihin suuntautuvaa toimintaa. On muistutettu, että olemassa olevat toimintamallit eivät aina vastaa sitä toimintavalmiutta, jota kansalaisten kanssa työskentelyssä tarvitaan. Diakonian on saatava rakennusaineksensa ja ilmaisunsa toimintaympäristöstään. (Latvus ym. 2005, 146.)

\section{Tutkimuksen tavoite, tutkimus- aineisto ja -analyysi}

Tässä artikkelissa kysyn, millaisia käsityksiä diakoniatyöntekijöillä on asiantuntijuudestaan taloudellisen avustustyön tehtävissä. Pohdin myös artikkelin lopussa, millaisia eroja on havaittavissa diakoniatyöntekijöiden taloudellisen avustustyön ja sosiaalityön asiantuntijuuden välillä.

Tutkimuksen aineistona ovat evankelis-luterilaisen kirkon 21 diakoniatyöntekijän teemahaastattelut ${ }^{7}$, jotka keräsin eri puolilla Suomea, kuuden hiippakunnan alueella sijaitsevista kaupunkiseurakunnista vuosien 2005-2006 aikana. Valitsin tutkimukseen seurakuntia 11 kaupungin alueelta, jotka olivat tilastojen perusteella lähettäneet usein asiakkaidensa hakemuksia diakoniarahastolle ${ }^{8}$. Oletuksena oli, että näissä seurakunnissa diakonian taloudellisen avun antaminen oli aktiivista. Keräsin aineiston teemahaastatteluin, koska menetelmänä se antoi väljyyttä keskustella myös niistä aiheista, jotka nousivat spontaanisti esiin haastattelujen aikana. Haastattelut perustuivat kolmeen keskeiseen teema-alueeseen, jotka koskivat diakonian taloudellisen avun muotoja ja avun tarpeen syitä, viimesijaisen sosiaaliturvan ongelmakohtia sekä diakoniatyöntekijöiden toimintaa yhteiskunnallisina vaikuttajina. Teema-alueista erityisesti ensimmäinen ja kolmas mahdollistivat keskustelun taloudellisen avustustyön asiantuntijuudesta. Sanatarkasti litteroituja haastatteluja kertyi 380 sivua. Tutkimukseen valituilla diakoniatyöntekijöillä oli vahva kokemus taloudellisesta avustamisesta, sillä heidän työuransa oli kestänyt keskimäärin 16 vuotta. Koulutukseltaan haastateltavat olivat diakonissoja, diakoneja ja seurakuntakuraattoreita. 
Teemahaastattelujen lisäksi olen käyttänyt tutkimusaineistona Espoon evankelis-luterilaisten seurakuntien ${ }^{9}$ diakoniatyöntekijöiltä kerättyä kyselyaineistoa, jonka avulla saatoin esittää haastatteluaineistoa täydentäviä ja tarkentavia kysymyksiä asiantuntijuudesta. Esitin kyselyssä avoimia kysymyksiä muun muassa diakoniatyön taloudellisen avustustyön asiantuntijuuden erityislaatuisuudesta. Lähetin kyselyn 37 diakoniatyöntekijälle, joista 22 vastasi kyselyyn. Vastaajista 12 oli koulutukseltaan diakoneja ja 10 diakonissoja. Työhistoriaa diakoniatyössä vastaajilla oli keskimäärin 11-15 vuotta. Toteutin kyselyn internetissä Helsingin yliopiston e-lomakkeella keväällä 2008.

Haastatteluaineistojen ja kyselyn analyysissä pyrin aineistotriangulaatioon eli halusin tarkastella kahden eri aineiston sisältöä samanaikaisesti yhdessä. Teemahaastattelujen ja kyselyn vastausten sisällönanalyysin tein aineistolähtöisesti ja teoriaohjaavasti. Analyysin ensimmäisen vaiheen toteutin aineistolähtöisesti, sillä kokosin aineistoista kaikki asiantuntijuuteen liittyvät ilmaisut. Toisessa vaiheessa jaoin asiantuntijuuteen liittyvät ilmaisut kahteen ryhmään, joista ensimmäinen sisälsi diakoniatyöntekijöiden asiantuntijuuden erilaiset sisällölliset ulottuvuudet ja toisessa olivat tekijät ja tilanteet, jotka diakoniatyöntekijät kokivat kehittävän ja kasvattavan heidän asiantuntijuuttaan. Analyysin kolmannessa vaiheessa käsittelin asiantuntijuusaineistoa teoriaohjaavasti. Tarkastelin, millä tavoin ryhmitellyssä aineistossa ilmenee yksilöllinen ja kollektiivinen asiantuntijuus. Tässä vaiheessa havaitsin, että yksilöllinen ja kollektiivinen asiantuntijuus ovat kietoutuneet toisiinsa. Toisinaan on mahdotonta havaita yksilöllisen ja kollektiivisen asiantuntijuuden erillisyyttä, minkä vuoksi analysoin diakoniatyöntekijöiden taloudellisen avustustyön asiantuntijuutta kokonaisvaltaisesti yksilön ja yhteisön/kollektiivin (esim. työyhteisö) näkökulmista.

Analyysin neljännessä vaiheessa jatkoin yksilöllisen ja yhteisöllisen asiantuntijuuden analyysiä. Hahmotin analyysissä osa-alueita, joiden avulla oli mahdollista jäsentää taloudellisen avustustyön asiantuntijuutta erilaisine sisällöllisine ulottuvuuksineen. Yksilölliseen asiantuntijuuteen liitin työntekijäkohtaisen asiantuntijuuden ja sen rakentumisen sekä yksilölliseen asiakastyöskentelyyn liittyvän asiantuntijuuden. Nimesin yksilöllisen asiantuntijuusalueen "yksilöllis-narratiiviseksi asiantuntijuudeksi". Yhteisöllisen asiantuntijuuden liitin verkostoissa työskentelemisen, mutta myös muun muassa taloudellisen avustamiseen

Kuvio 1. Diakoniatyöntekijöiden taloudellisen avustustyön asiantuntijuuden osa-alueet

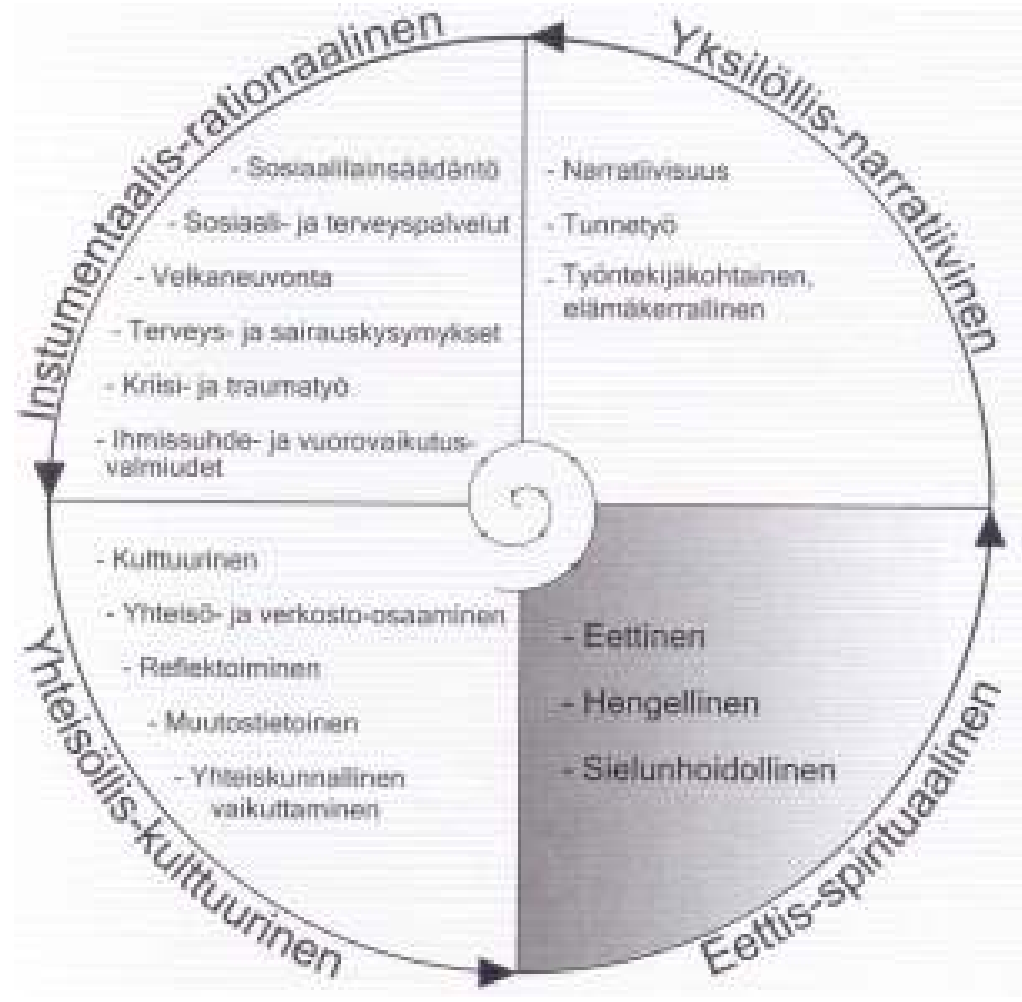


liittyvän yhteisöllisen ja yhteiskunnallisen työn asiantuntijuuden. Yhteisöllinen asiantuntijuusalue sai nimekseen "yhteisöllis-kulttuurinen asiantuntijuus". Yksilöllisen ja yhteisöllisen asiantuntijuuden lisäksi aineistosta saattoi nostaa omaksi osaalueekseen taloudellisen avustustyön eettisen perustan ja - toiminnan sekä hengellisen työn eri muodot. Nimesin osa-alueen "eettis-spirituaaliseksi asiantuntijuudeksi”. Omaksi ryhmäkseen muodostuivat myös taloudellisen avustustyön keskeiset välineelliset tiedot ja taidot, jotka olivat suurimmalle osalle työntekijöistä yhteisiä. Nimesin alueen "instrumentaalis-rationaaliseksi ${ }^{10}$ asiantuntijuudeksi". Vaikka taloudellisen avun asiantuntijuudesta oli mahdollista löytää omat erilliset osaalueet, niin alueet ovat vahvasti yhteydessä toisiinsa, osin tiettyjä ulottuvuuksia on vaikea erotella toisistaan. Seuraavissa luvuissa tuon esille jokaisen asiantuntijuusosa-alueen keskeisimmän sisällön. ${ }^{11}$ Kuvioon 1 olen sijoittanut diakoniatyöntekijöiden taloudellisen avustustyön keskeiset osaalueet.

\section{TULOKSET}

\section{Instrumentaalis-rationaalinen asiantuntijuus}

Instrumentaalis-rationaalinen asiantuntijuus sisälsi taloudellisen avustamisen välineelliset tiedot ja taidot, jotka olivat perustana taloudellisen avustamisen toteuttamiselle. Keskeisimpänä osana instrumentaalis-rationaaliseen asiantuntijuuteen kuuluivat sosiaali- ja terveyslainsäädännön ja yhteiskunnan palvelurakenteen tunteminen. Erilaiset ihmissuhde- ja vuorovaikutustaidot voitiin niin ikään nähdä osana instrumentaalis-rationaalista asiantuntijuutta.

Instrumentaalis-rationaalisessa asiantuntijuudessa keskiössä oli monenlainen erityistieto muun muassa työn kohdeongelmista, asiakkaiden tilanteista ja erilaisista työmenetelmistä (vrt. Karvinen 1996, 39; Pohjola 2007, 15). Diakoniatyön taloudellisessa avustustyössä korostui erityisesti yhteiskunnallisen sosiaalilainsäädännön ja palveluja etuusjärjestelmän tunteminen. Näiden edellä mainittujen tietoalueiden merkitys perustui muun muassa siihen, että taloudellisen avustamisen perusteiden kartoittamisessa selvitettiin asiakkaiden etuuksien ja palvelujen saanti julkiselta sektorilta sekä ohjattiin asiakkaita palvelujen piiriin.
Lainsäädännöstä sekä yhteiskunnallisten palvelu- ja etuusjärjestelmien tunteminen; muutoksia tulee koko ajan ja sen tiedon hankkiminen ja sen kanssa ajan tasalla pysyminen vaatii aikaa ja vaivannäköä, jota välillä ei perustyön rinnalla tunnu ehtivän ja jaksavan. (Vastaaja 4)

Useat taloudellisen avun asiakkaat olivat velkaantuneita, joten diakoniatyön taloudellinen avustustyö alkoi monissa tapauksissa velkatilanteen selvittelyllä. Velkaneuvonnan perustana oli tilanteen läpikäyminen ja velkojen määrän selvittäminen, sillä usein asiakas oli velkaa monelle eri taholle ja velat olivat ulosotossa. Velkaantumisen syiden ja seurausten selvittelyn lisäksi diakoniatyöntekijät pyrkivät vastamaan asiakkaan "velkapaniikkiin", mikä merkitsi ensisijaisesti diakoniatyöntekijöiden kykyä nähdä asiakkaan voimakkaasta velkaantumisesta johtuva lamaannus ja toivottomuus. Asiakkaiden velkojen selvittely oli johtanut työntekijöitä myös palvelujärjestelmän kehittämistyöhön, esimerkiksi vaatimukseen saada kaupunkikohtaisesti sosiaalinen luototus ${ }^{12}$.

Diakoniatyöntekijät painottivat sairauksiin ja terveydenhoitoon liittyvien seikkojen laajaa tuntemusta, sillä usein taloudellisilla ongelmilla on yhteyksiä asiakkaan sairauksiin tai sairaudet olivat syynä taloudellisiin vaikeuksiin:

[Tarvitaan] sairaanhoidolliset tiedot ja taidot. Henkiset ja fyysiset sairaudet vaikuttavat kokonaisuuteen ja asiakkaan kykyyn hahmottaa ja hoitaa asioita. Ihmisen taloudellinen avustaminen on vain pieni osa ihmisen auttamisesta. (Vastaaja 20)

Diakoniatyöntekijät huomauttivat, ettei taloudellisia ja terveydellisiä ongelmia voinut lopulta edes erottaa toisistaan. Tietoa tarvittiin asiakkaiden terveyttä uhkaavien riskitekijöiden sekä sairauksien tunnistamiseen. Merkittävintä oli se, että työntekijät osasivat ohjata asiakkaitaan vastaanotoiltaan tai kotikäynneiltään terveydenhoitopalvelujen piiriin.

Diakoniatyön taloudellisen avustamisen perusteina voivat olla yllättävät ja ennakoimattomat tilanteet. Kyse oli usein erilaisista kriiseistä, jolloin kriisi- ja traumatyön osaaminen olivat merkittävässä osassa taloudellisen avustustyön asiantuntijuudessa. Kriisiytyneet elämäntilanteet johtuivat esimerkiksi sairauksista, onnettomuuksista tai kuolemantapauksista. Kriisityön asiantuntijuuteen kuuluivat kriisin vaiheiden ja niihin liittyvien ulot- 
tuvuuksien, muun muassa tunneskaalojen tunteminen sekä kriisiin sopivien auttajaverkostojen hakeminen ja luominen.

Instrumentaalis-rationaaliseen asiantuntijuuteen kuuluivat myös erilaisten ihmissuhde- ja vuorovaikutustaitojen perusvalmiudet. Lähtökohtaisesti ihmissuhde- ja vuorovaikutustaidot tarkoittivat diakoniatyöntekijöiden kykyä toimia ja viestiä erityyppisissä työtilanteissa, jotka vaihtelivat työpäivän aikana useita kertoja. Useimmiten tilanteet sisälsivät asiakkaan kohtaamista, diakoniatyöntekijöiden keskinäistä vuorovaikutusta sekä työskentelyä moniammatillisissa verkostoissa. Diakoniatyöntekijät kuvasivat toimivansa usein "välittäjinä" tai "tulkkeina" asiakkaiden ja sosiaaliviranomaisten välissä. Diakoniatyöntekijät sanoittivat asiakkaalleen uudelleen esimerkiksi hänen saamansa etuuspäätöksen tai diakoniatyöntekijä välitti asiakkaan tuen tarpeen sosiaaliviranomaisille. Kyseessä oli asiakkaan puolesta puhuminen ja asianajo (Mäkeläinen \& Mäkeläinen 1999, 52).

Instrumentaalis-rationaalisen asiantuntijuuden ulottuvuudet osoittavat, että jo taloudellisen avustustyön perusvalmiuksien kohdalla työntekijät tarvitsivat erittäin monenlaista asiantuntijuutta. Diakoniatyöntekijöiden asiantuntijuutta kuvaavissa esimerkeissä heijastui muutospuhe siitä, kuinka asiantuntijuuden vaatimukset ovat kasvaneet erityisesti 1990-luvun laman jälkeen:

Silloin kun mä opiskelin diakonissaksi, niin oli ongelma ja ongelmalle esitettiin tavoite ja keinot ja sitten arviointi...ja se oli siinä. Se oli nelijakokenttä, että näin tehdään. Mutta sitten kun tuli lama, niin oli taloudellinen asia, oli sairaus, oli asuntosysteemit, velat ja työttömyys... siis kaikki...että lasten kasvatusongelmat ja avioongelmat. Ja sitten kun alkoi katsoa sitä nelikenttää, että miten tämä nyt skulaa, kun on kymmenen ongelmaa sen yhden sijasta. (H06)

\section{Yksilöllis-narratiivinen asiantuntijuus}

Yksilöllis-narratiivinen asiantuntijuus osoittautui omaksi vahvaksi alueekseen. Taloudellisen avun asiantuntijuus oli kietoutunut vahvasti sekä asiakkaan että työntekijän elämänhistoriaan ja tunne-elämään. Taloudellisessa avustustyössä asiakkaan kohtaamisen perustana olivat instrumentaalis-rationaalisen asiantuntijuuden ihmissuhde- ja vuorovaikutustaidot, mutta tässä narratiiviisuudel- la tarkoitetaan yksilön kohtaamisen syvällistä asiantuntijuutta. Kyseessä oli Tikkamäen (2007, 259) määrittelyä seuraten asiakkaan kokonaisvaltainen ja lähimmäisen rakkauteen perustuva syvä kohtaaminen, joka perustana on asiakkaan elämäntarinan ymmärtäminen sekä asiakkaan ja työntekijän välinen avoin dialogi.

Taloudellisessa avustustyössä merkittävää oli se, että asiakas kohdattiin yksilönä, ja työntekijällä oli valmius kuulla ja nähdä hänen todellinen elämäntilanteensa sekä pyrkiä osallistumaan asiakkaan kokemuksiin. Yksilöllis-narratiivinen asiantuntijuus perustui yksilön elämäntarinan, -kokemuksen ja -tulkinnan kuulemiseen, mitä voidaan Molanderin $(2003,34)$ tavoin kutsua myös biografiseksi työksi.

Niin tuo kohtaaminen...se tuli esille, että kuinka monenlaiset on ne asiat...ja, se luottamus tulee siitä kohtaamisesta, se alkaa suhteen rakentamisesta...vaikka sen ihmisen ongelmat olisi kuinka moninaiset tahansa. Se alkaa suhteesta...ja se, että siinä on se ihminen, jolla onpi monta asiaa. Ja monien taakka on iso. Täytyy olla uskallusta kohdata sinä ja sinun taakat.- Se on ihan niinku luonnollinen asia, että kun saa henkilökohtaisesti kertoa juttua niin sitä tulee ymmärrystä enemmän. (H10)

Kuten edellisessä lainauksessa diakoniatyöntekijä toi esille, tärkeää yksilön tarinan jakamisessa oli luottamuksen rakentuminen asiakaan ja työntekijän välille. Luottamuksen rakentamisen perusteiksi nähtiin työntekijän taito kuunnella, ajan ja tilan antaminen asiakkaalle sekä asenne, jossa työntekijä ja asiakas olivat samalla tietämisen viivalla. Usein luottamuksen rakentamiseen tarvittiin pidempiaikaista prosessimaista työskentelyä, jonka aikana työntekijä oppi myös kuulemaan asiakkaan kertomatta jättämiä asioita. Diakoniatyöntekijät toteuttivat luottamustyötä, jolla pyrittiin hälventämään sellaista epäilyksen ja epäluottamuksen kulttuuria, jossa asiakas oli tottunut elämään (ks. Mattila-Aalto 2007, 274-275; Molander 2003, 34). Työntekijä pyrki rohkaisemaan asiakasta, osoitti myötätuntoa ja empatiaa sekä etsi tämän voimavaroja. Toisinaan tärkeäksi koettiin myös elämän rajoista keskusteleminen ja niiden laatiminen. Diakoniatyössä korostui näin ollen kasvatuksellinen asiantuntijuus (Forsseìn 2005, 90-91).

Diakoniatyöntekijät kokivat asiakkaan elämäntarinan ymmärtämisessä merkittäväksi tunnetyön 
osaamisen. Tunnetyössä olivat mukana niin asiakkaan kuin työntekijän tunteet, sillä keskeiseksi koettiin asiakkaan tukeminen tunteidensa ilmaisussa ja niiden ymmärtämisessä sekä diakoniatyöntekijän omien tunteiden hallitseminen. Asiakastilanteet saattoivat nostaa työntekijöissä niin säälin, surun, pettymyksen ja vihankin tunteita. Pettymyksen tunteet kohdistuivat esimerkiksi asiakkaan, sosiaaliviranomaisten tai asiakkaan läheisten tekemiin ratkaisuihin, jotka olivat kurjistaneet asiakkaan tilannetta entisestään. Asiakastyöskentely toi työntekijälle myös iloa ja onnistumisen tunteita, jotka sisälsivät vakuuttuneisuuden omaa ammatillista osaamista kohtaan ja ilon asiakkaan puolesta:

Mulla on muutama sellainen asiakas, josta mä oon tavattoman iloinen ja saa nostaa itselleen hattua, että ovat tehneet oman elämänsä eteen ison askeleen. Että oon - jutellu heidän kanssaan ja saanut motivoituu. Että hei...haluutko sä jatkaa tätä tiukkaa ahdinkoo vai lähdetkö sä vuodeksi tai kahdeksi kouluun. - Et pistää ihmiset ite ajattelemaan, ja että he ite päättää, että mä ihan oikeesti haluun muuttaa omaa elämää ja mulla on kakskytvuotta eläkkeeseen aikaa. Eli tunnen yhden bussikuskin, joka valmistuu nyt. Ja yksi viiskymppinen kirjoitti nyt ylioppilaaksi, entinen alkoholisti. (H7)

Usein diakoniatyön taloudellisessa avustamisessa tunnetyö merkitsi työntekijöille kykyä ymmärtää ja suhtautua empaattisesti asiakkaan tunteisiin ja asenteisiin, jotka olivat usein myös kielteisesti sävyttyneitä. Toistuvat pettymykset, epäonnistumiset ja pois käännyttämiset saattoivat hallita asiakkaiden tunteita ja ne välittyivät suhtautumisena diakoniatyöntekijään. Asiakastyössä esiin tulevat tunteet on katsottu toimivan työntekijälle mahdollisuutena eläytyä ja olla aidosti läsnä asiakkaan tilanteessa (Tikkamäki 2007, 259; Mäkeläinen \& Mäkeläinen 1999, 51), mutta toisinaan diakoniatyöntekijät kokivat, että kielteiset tunteet muuttivat heidät pessimistisiksi ja jopa usko oman työn mahdollisuuksiin heikkeni.

Taloudellisen avustustyön asiantuntijuus liittyi vahvasti asiakkaan elämänhistoriaan, mutta myös työntekijän omat elämäntapahtumat osoittautuivat tärkeiksi. Yksilöllis-narratiivista asiantuntijuutta vahvistivat yksittäisen työntekijän oma elämänhistoria, koulutus-, työ- sekä muut elämänkokemukset kuten perhe-elämä, erilaiset ihmissuh- teet ja harrastukset. Työntekijän elämänhistoria nähtiin pääosin asiantuntijuutta vahvistavana, eikä sen kielteisiä vaikutuksia ammatilliseen toimintaan juuri arvioitu (ks. Karvinen 1996, 23). Kosonen $(2005,76)$ puhuu "elämäkerrallisesta muistista", joka sisältää muun muassa ajatuksen siitä, että elämäntapahtumat ovat sosiaalisesti jaettavia. Diakoniatyöntekijät saattoivat oman elämänhistorian kautta olla osallisena myös asiakkaidensa kokemuksissa. Erityisesti kokemukset työntekijän omista kriiseistä ja vaikeuksista sekä niistä selviämisistä tukivat asiakkaiden haastavien elämäntilanteiden kohtaamista:

Oma elämänprosessi vaikeuksineen ja itselle tuen hakeminen ja saaminen ovat olleet auttamistyössä tärkeitä asiantuntijuuden kehittymisessä. Oma terapia, oma työnohjaus ja kollegojen kanssa käydyt pohdinnat ovat olleet tärkeitä. (Vastaaja 9)

Elämänkokemus toi työntekijälle niin sanottua hiljaista tietoa, joka merkitsi erityisesti työntekijän intuitiota ja herkkyyttä ajatella ja toimia tehtävien vaatimalla tavalla.

\section{Yhteisöllis-kulttuurinen asiantuntijuus}

Yhteisöllis-kulttuuriseen asiantuntijuuteen liittyi taloudellisen avustamisen kontekstissa niin kulttuurien ja yhteisöllisten siteiden tunnistamista kuin myös taitoja toimia verkostoissa ja yhteisöllisyyden mahdollistajana.

Taloudellisessa avustustyössä kulttuurinen asiantuntijuus tarkoitti asiakkaiden, esimerkiksi etnisten, kulttuuritaustojen sekä paikkakuntakohtaisten kulttuurien tuntemusta. Kulttuurien tuntemus tarjosi työntekijälle mahdollisuuden vuorovaikutukseen asiakkaan kanssa, ja siten asiakkaan taustatilanteen ja diakonian taloudellisen avun tarpeeseen johtavien tekijöiden ymmärtämisen. Ensisijaista paikallisten kulttuurien ja olosuhteiden ymmärtämisessä oli se, että diakoniatyöntekijät toimivat vahvasti kaupunkien lähiöissä eli he työskentelivät asiakkaidensa jokapäiväisessä toimintaympäristössä. Osallisuus asiakkaiden toimintaympäristöön saattoi mahdollistaa asiakkaiden kulttuuristen ja yhteisöllisten käytäntöjen, arvojen ja normien tiedostamisen.

Kulttuurinen asiantuntijuus muodosti yhteisöja verkosto-osaamisen perustan, sillä siihen kuu- 
lui taloudellisen avun asiakkaiden yhteisöjen ja verkostojen tunnistaminen ja niiden merkityksen ymmärtäminen asiakkaan elämässä. Tärkeää oli kartoittaa, oliko asiakkaalla olemassa olevia verkostoja, joista hän voi saada tukea ja apua tilanteessaan. Taloudellisen avun asiantuntijuuteen kuului myös sellaisten tekijöiden ymmärtäminen, joilla oli vaikutus kokonaisten yhteisöjen, esimerkiksi naapuruston, hyvinvointiin:

Ja aina kun jotain kauheaa tapahtuu, niin se ei koske vaan yhtä ihmistä, vaan se on laaja yhteisö. Vuosia sitten tässä minun lähellä tapahtui kaksi murhaa. Tapettiin kaksi minun asiakasta. Niin pitkään meni, että naapureita ja heidän kavereita tuli asioimaan minun luokse, niin kyllä he usein siitä puhu. He tuli rahan takia, mutta kyllä me sitä surutyötä läpikävimme. (H12)

Yhteisö- ja verkosto-osaamiseen kuului vahvana osa-alueena yhteisöllisyyden luominen. Diakoniatyöntekijät ohjasivat taloudellisen avun asiakkaitaan osallistumaan erilaiseen julkisen - ja kolmannen sektorin toimintaan, mutta myös seurakunnilla itsellään oli huomattava määrä erilaisia osallistumisen mahdollisuuksia. Jos seurakunnassa ei ollut olemassa olevaa, asiakkaan elämäntilanteeseen ja toiveisiin soveltuvaa pienryhmää, diakoniatyöntekijät saattoivat järjestää esimerkiksi vertaisryhmiä tai leirejä ja kutsua niihin mukaan samantapaisessa elämäntilanteessa eläviä asiakkaitaan.

Taloudellisen avustustyön toteuttamisen edellytykseksi nostettiin moniammatillinen yhteistyö, joka merkitsi diakoniatyöntekijöiden toimimista lukuisissa verkostoissa ja liikkumista niiden välillä. Verkosto-osaamisessa korostui yhteistyö sosiaali- ja terveyspalveluiden alalla toimivien kanssa. Tärkeimmäksi yhteistyökumppaniksi määriteltiin sosiaalitoimi. Yhteistyö sosiaalitoimen kanssa merkitsi ennen kaikkea asiakkaan auttamista, joka mahdollistui muun muassa toisten palveluihin ohjaamisen ja tietojen vaihtamisen kautta. Yhteistyössä koettiin tärkeäksi osapuolien toimintakulttuurien tuntemus, mutta siinä nähtiin olevan myös jatkuvan kehittämisen paikka. Diakoniatyöntekijöiden haastatteluaineistossa nousi esille puhe oman asiantuntijuutensa vakuuttamisesta, diakonian erityisen tehtävän ilmentämisestä ja paikkansa löytämisestä osana sosiaalityön toimintaympäristöä mutta myös osana kaupunkikohtaista hyvinvointityön auttamisverkostoa:
Ja me työntekijät kyllä satsataan siihen, että ollaan paljon yhteistyössä ja vakuutetaan sitä kautta yhteistyökumppaneille, että me ollaan tasavertaisia ja me tajutaan asioista, missä mennään ja me ymmärretään juttuja. Ja tietoo tulee paljoon, kun tekee yhteistyötä. Kun jaksaa vaan tehdä asiakastasolla ja asiakkaiden kanssa yhteistyötä, tavoitteellisesti ja pitkäjännitteisesti... se kai vakuuttaa. Nyt on pakko tehdä yhteistyötä, kun asiat on sellaisia, että asiantuntemus ei riitä oikein millään tasolla. (H21)

Merkittävintä yhteistyötä diakoniatyöntekijät tekivät omien kollegoidensa kanssa. Tärkeää oli informaation vaihtaminen ja välittäminen, mutta tätäkin merkittävämmäksi koettiin reflektiomahdollisuudet kollegoiden kesken. Asiakastapausten, työntekijän tekemien ratkaisujen, asenteiden ja tunteiden reflektointi muodostui asiantuntijuuden kehittymisen kannalta olennaiseksi seikaksi, ja siihen toivottiin löytyvän aikaa ja mahdollisuuksia nykyistä enemmän. Yhteisen jakamisen konkreettinen merkitys perustui myös yhdessä oppimiseen ja työssä jaksamiseen (vrt. Forsseìn 2005).

Yhteistyön merkitys nousi esille myös yhteisöllis-kulttuurisen asiantuntijuuteen kuuluvan muutostietoisuuden kohdalla, joka oli perustana diakoniatyön muutostyölle (vrt. Pohjola 2007, 6). Muutostietoisuus tarkoitti esimerkiksi sitä, että diakoniatyöntekijät tiesivät, millaisia muutoksia tapahtui paikallistasolla sosiaaliturvan myöntämistä koskevissa käytänteissä, sillä muutokset heijastuivat nopeasti diakoniatyöntekijöiden työhön ja taloudellisen avun tarpeisiin. Asiakastasolla muutostietoisuus sisälsi tulkinnan siitä, millaiset tapahtumat asiakkaan elämässä olivat johtaneet tapahtumasta toiseen, aiheuttaneet vakavia taloudellisia ja sosiaalisia ongelmia ja miten diakoniatyön taloudellisen avustamisen keinoin voitaisiin saada muutosta asiakkaan elämisen mahdollisuuksiin.

Muutostietoisuus muodosti perustan diakoniatyöntekijöiden yhteiskunnalliselle vaikuttamiselle, sillä työntekijöiden tuli olla tietoisia asiakkaita koskettavista paikallis- ja valtakunnallisen tason muutoksista, sillä ne olivat saattaneet vaikuttaa heikentävästi esimerkiksi asiakkaiden sosiaalietuuksien ja -palvelujen saatavuuteen. Valmiudet vaikuttaa taloudellisen avustustyön kontekstissa asiakkaita koskeviin epäoikeudenmukaisuuksiin olivat muodostuneet merkittäväksi osaksi diakoniatyöntekijöiden työnkuvassa. Työntekijät 
kokivat, että yhteiskunnallista vaikuttamista tarvitaan koko ajan enemmän, mutta vaikuttamistyötä pidettiin yhtenä vaikeimmista työmuodoista, eikä siihen ollut aina aikaa, voimia eikä halua.

\section{Eettis-sprituaalinen asiantuntijuus}

Eettis-sprituaalinen asiantuntijuus muodosti taloudellisen avustustyön perustan ja erityisyyden sekä profiloi diakoniatyöntekijät kirkon työntekijöiksi.

Eettinen asiantuntijuus perustui Raamatun sanoittamaan lähimmäisen rakkauteen ja se määritteli kaikkia diakoniatyöntekijöiden tehtäviä. Lähimmäisen rakkaus merkitsi taloudellisen avustustyön kontekstissa sitä, että jokainen apua tarvitseva ihminen edusti Jumalan luomaa ainutlaatuista yksilöä. Olennaista oli herkkyys nähdä asiakkaan mahdollisuudet ja toivon herättäminen kipeässä elämäntilanteessa. Eettinen asiantuntijuus tarkoitti asiakkaan yksilöllisen ihmisarvon tunnustamisen lisäksi velvollisuutta ja valmiutta herättää arvokeskustelua laajemmin yhteiskunnassa. Arvoihin perustuvan keskustelun herätteleminen tarkoitti käytännön työn tasolla esimerkiksi asiakkaan perusoikeuksien ja vahvan hyvinvointivaltion puolustamista:

Ja kyllä mä nään, että köyhät ihmiset, hyvin harvalla on sisua lähtee puolustamaan itseään ja puolustamaan köyhän oikeuksiaan. - Me voitas ihmisten rinnalla olla tukemassa heidän oikeuksissa. Ja minä näkisin, että diakoniatyö on myös hyvinvointivaltion arvojen puolustamista... ruohonjuuritasolta. (H18)

Taloudelliseen avustustyön kokonaisuuteen diakoniatyöntekijät liittivät hengellisen auttamisen ja tukemisen. Hengelliseen asiantuntijuuteen kuului tietoisuus siitä, mitä uskonto ja hengellisyys voivat merkitä asiakkaan hyvinvoinnissa ja elämän merkitysten etsinnässä. Hengellisen asiantuntijuuden keskiössä oli myös diakoniatyöntekijän henkilökohtainen uskonnollinen vakaumus, ja oman kutsumustietoisuutensa kautta diakoniatyöntekijät kokivat ymmärtävänsä sen, millä asialla he lähtökohtaisesti olivat kirkon työntekijöinä. Heidän tehtävänsä oli välittää ja toteuttaa sanomaa Jumalasta ja armosta. Hengellistä asiantuntijuutta piti yllä ja uudisti yksilöllinen ja työyhteisössä jaettu hengellisyys ja hiljentyminen.
Mitä tää mun paikka Jumalan näkökulmasta oikein on. Jotenkin pitäisi sitä siinä omassa työnäyssä, että menee ja tiedostaa ne haasteet, joita yhteiskunnasta tulee. Mutta ei mun mielestä diakoniatyön tehtävä oo kuitenkaan lähtee vastamaan kaikkiin huutoihin vaan vastata huutoihin joskus sillä, että kuule sä...että me ollaan sen takia, että ihmiset oppisi tuntemaan enemmän Jumalaa ja armoo, joka on kaikille lahja. (H01)

Muutamat haastatelluista diakoniatyöntekijöistä kertoivat, kuinka henkilökohtainen hengellinen kutsumus oli vaikuttanut työn suuntaamiseen, mutta myös asiantuntijuuden vahvistamiseen tietyissä diakoniatyön tehtävissä:

Jumala ei tuonut mua tänne vanhustyöhön, vaan jotain muuta varten. Ja mä oon kokenut ja oon pitänyt esillä väliinputoajien ja syrjäytyneiden puolestapuhumista. (H13)

Eettiseen ja hengelliseen asiantuntijuuteen liittyi sielunhoidollinen asiantuntijuus. Sielunhoidollinen asiantuntijuus sisälsi erilaisia tiedollisia ja taidollisia menetelmiä sielunhoidon toteuttamiselle. Ensisijaista diakoniatyöntekijöille oli tukea asiakasta löytämään elämän mielekkyys ja arvo, sillä useat asiakkaat olivat kokeneet elämässään raskaita pettymyksiä ja epäonnistumisia ja osa oli masentuneita ja uupuneita. Diakoniatyöntekijät toteuttivat "käytännön spiritualiteettia" (Tirri 2005, 105), joka ilmeni inhimillisenä huolenpitona, toisten vahvistamisena ja yhteenkuuluvaisuuden tunteen välittämisenä sekä hiljentymisenä.

Vaikka eettis-spirituaalinen asiantuntijuus osoittautui diakoniatyöntekijälle yhdeksi vahvimmista ja ominaislaatuisimmista asiantuntijuusalueista, niin osa työntekijöistä kaipasi tukea juuri hengelliseen työhön:

[Tarvitsen] rukoilemisen "oppimista" niin, että voi rukoilla asiakkaiden kanssa ja myös keskustella hengellisistä asioista. Ei siis välttämättä teologiaa, vaan uskontoa ja hengellisyyttä! En myöskään tarkoita seurakunnan perinteen tuntemusta vaan elävää hengellistä elämää ja sekä oppimista ja keskustelusta siitä.-. Olemme seurakunnan työntekijöitä, se on tärkein muistaa. (Vastaaja 23) 


\section{Diakoniatyön moniulotteinen asiantuntijuus}

Tämän artikkelin tavoitteena oli tutkia, millaisia käsityksiä diakoniatyöntekijöillä on asiantuntijuudestaan taloudellisen avustustyön tehtävissä. Tulosten perusteella pohdin tässä, millaisia eroja on havaittavissa diakoniatyöntekijöiden taloudellisen avustustyön ja sosiaalityön asiantuntijuuden välillä.

Diakoniatyöntekijöiden taloudellisen avustustyön asiantuntijuudesta oli mahdollista muodostaa neljä laajaa osa-aluetta, jotka nimesin instrumentaalis-rationaaliseksi, yksilöllis-narratiiviseksi, yhteisöllis-kulttuuriseksi ja eettis-spirituaaliseksi asiantuntijuudeksi. Tulosten perusteella voidaan sanoa, että diakoniatyöntekijöiden taloudellisen avun asiantuntijuudessa ilmenee asiantuntijuuden yksilöllinen ja kollektiivinen luonne. Yksilöllinen asiantuntijuus voidaan selvimmin paikantaa yksilöllis-narratiiviseen asiantuntijuuteen ja sen sisältämiin työntekijän yksityis- ja työelämän kokemuksiin. Kollektiivinen asiantuntijuus nousee esille konkreettisimmin diakoniatyöntekijöiden yhteisöllis-kulttuurisen asiantuntijuuden ja erityisesti sen yhteisö- ja verkosto-osaamisen kohdalla. Kaikissa asiantuntijuuden osa-alueissa yksilöllinen ja kollektiivinen asiantuntijuus liittyvät vahvasti yhteen. Esimerkiksi yksilöllis-narratiivinen asiantuntijuus sisältää vahvaa kollektiivisuutta, sillä asiantuntijuus ilmenee ja rakentuu diakoniatyöntekijän ja asiakkaan kohtaamisen, dialogin ja erityisesti elämäntarinan kerronnan kautta. Asiakkaan elämäntarinan jakaminen mahdollistaa diakoniatyöntekijän eläytyvän, osallistuvan ja elämänkirjon moninaisuuden ymmärtämiseen perustuvan asiantuntijuuden.

Tulokset osoittavat, että diakoniatyöntekijöillä on taloudellisessa avustustyössään paljon erilaista vertikaalista asiantuntijuutta eli sellaista professionaalista tietoa ja osaamista, joita esimerkiksi asiakkailla ei ole (Juhila 2006, 84-85). Tuloksia luonnehtii kuitenkin vertikaalista asiantuntijuutta vahvemmin horisontaalinen asiantuntijuus, joka merkitsee Juhilan (2006) määritelmän mukaan asiantuntijuuden rakentumista asiakkaan ihmisarvon ja elämäntilanteiden ainutlaatuisuuden tunnustamisen ja asiakkaan oman äänen kuulemisen kautta. Diakonian asiakastyössä asiakkaan omat tulkinnat auttamisen syistä ovat välttämättömiä ymmärtävän kohtaamisen ja avun kohdentamisen kan- nalta, mikä on vain korostunut toimintaympäristön ja asiakastilanteiden moninaistuessa. Asiakkaiden yksilöllisiin eroihin ja transkulttuurisuuteen perustuva asiantuntijuus ja toimintamenetelmät ovat myös kunnallisen sosiaalityön perustavana tavoitteena, mutta ainakin toimeentulotukiasiakkuuksissa, horisontaalinen asiantuntijuus jää usein saavuttamattomaksi ihanteeksi (Juhila 2006, 148).

Horisontaalisen asiantuntijuuden lisäksi tulokset kuvaavat diakoniatyöntekijöitä yhteisö- ja alueperustaisen työn ${ }^{13}$ vahvoina osaajina. Taloudellinen avustustyö perustuu asiakkaiden henkilökohtaiseen kohtaamiseen mutta myös tämän elinolosuhteisiin ja toimintaympäristöön tutustumiseen ja niiden vaikutusten arviointiin asiakkaiden hyvinvointiin (Juntunen 2009). Diakoniatyössä toimitaan läheisyysperiaatteeseen nojautuen, sillä asiantuntijuus rakentuu havainnoille, kokemuksille ja eläytymiselle paikallistasolla asiakkaan elämänpiiriin ja -tilanteisiin (vrt. Roivainen 2008, 254-255). Diakoniatyö etsii ja luo asiakkaillensa luonnollisia ja yhteisöllisiä liittymisen mahdollisuuksia. Kun yhteisö- ja alueperustaiset työmenetelmät näyttävät varsin vahvoilta diakonian työmuodoilta, ovat ne lähes hävinneet sosiaalityöstä. Suomalainen kunnallinen perussosiaalityö on viime vuosina eriytynyt yhä enemmän asiakasryhmittäin. Sosiaalityö on organisoitunut ilmiöperustaiseksi (esim. päihdetyö) tai ikä- ja väestöryhmäperustaiseksi (esim. nuorisososiaalityö, aikuissosiaalityö). (Roivainen 2008, 258; 276; Pohjola 2007, 9.)

Diakoniatyön taloudellisen avustustyön asiantuntijuuden osa-alueet sekä niiden luonnehtiminen horisontaalisiksi ja yhteisö- ja alueperustaiseksi osaamiseksi piirtävät kuvaa yhteisyyden ja yksilöllisyyden diakonisesta asiantuntijuudesta. Diakoniatyön asiantuntijuutta ohjaa holistinen ihmiskäsitys, jossa ihminen kohdataan Rauhalan (2005, 32-47) käsittein tajunnallisena, kehollisena ja situaationalisena toimijana. Käsitys ottaa huomioon yksilön kaikkine olemusulottuvuuksineen sekä sen yhteisön ja sosiaalisen kentän, jossa ihminen elää ja toimii. Holistisen asiantuntijuuden ylläpitämisen ja kehittämisen esteiksi voivat muodostua kuitenkin diakoniatyön kasvavat asiakasvirrat, byrokratisoituminen tai ammatillisen yhteistyön vaikeudet. Yhteistyötä saattavat tulosten perusteella vaikeuttaa se, että diakoniatyössä joko koetaan epävarmuutta oman asiantuntijuutensa arvostuksesta tai diakoniatyö ja sosiaalityö ovat ajautuneet kilpailuasetelmiin, jossa molemmat osapuolet pitävät merkityksellisimpänä vain omaa asi- 
antuntemustaan. Vaarana on, että diakoniatyössä ja sosiaalityössä ei synny aitoa, jaettua asiantuntijuutta ja solidaarisuutta, jonka puitteissa voitaisiin yhdessä luoda hyvinvointia eriarvoisuuden vähentämiseksi.

Diakoniatyöntekijät itse arvioivat eettis-spirituaalisen ominaislaatuisimmaksi asiantuntijuudekseen, joka ilmentää myös selkeimmin eroa diakoniatyön ja sosiaalityön asiantuntijuuden välillä. Diakoniatyön lähtökohdaksi määritellään kristillinen lähimmäisen rakkaus, joka ilmenee Jumalan luoman ainutlaatuisen ihmisen kohtaamisena, elämän pyhyyden vaalimisena ja armon välittämisenä. Spirituaalisen asiantuntijuuden soveltamista pidetään toisinaan vaikeana soveltaa taloudellisessa avustustyössä, vaikka toisaalta spirituaalinen asiantuntijuus nähdään auttamistyön voimana ja ammatti-identiteetin rakentumisen perustana. Diakoniatyön nopeiden muutosten myötä on mahdollista, ettei diakoniatyöntekijöillä ole ollut kuitenkaan riittävästi aikaa, tilaa, voimavaroja eikä työyhteisön sosiaalista ja emotionaalista tukea tehdä yksilöllistä ja yhteistä ammatillista identiteettityötä. Diakoniatyöntekijän ammatillisen toimijuuden, tavoitteiden, arvojen ja etiikan aikaisempaa analyyttisempi määrittely työyhteisöissä voisi luoda taloudellisen avustustyön kontekstiin vahvempaa ja käytännön taloudellista avustustyötä eriytymättömänä osana palvelevaa sprituaalista asiantuntijuutta. Eettis-spirituaalista asiantuntijuutta tulisi vaalia, sillä se on diakoniatyön ja koko kirkon ainutlaatuista, auktoritatiivista ja arvovaltaista tietoa, jolla on todellista vaikutusvaltaa sekä yleispätevää yhteisöllistä ja yhteiskunnallista jaettavuutta ja hyödynnettävyyttä (vrt. Eräsaari 2006, 193).

\section{Lähteet ja kirjallisuus}

Aalto-Mattila, M. (2007). Inklusiivinen asiantuntijavuorovaikutus päihdekuntoutuksessa. Aikuiskasvatus 27 (4), 266-278.

Desforges, C. (1995). How does experience affect theoretical knowledge for teaching? Learning and Instruction 5, 385-400.

Eräsaari, R. (2006). Yhteisten asioiden virallinen asiantuntija. Janus, 14 (2), 182-195.

Eteläpelto, A. \& Vähäsantanen, K. (2006). Ammatillinen identiteetti persoonallisena ja sosiaalisena konstruktiona. Teoksessa Eteläpelto,
A. \& Onnismaa, J. (toim.) Ammatillisuus ja ammatillinen kasvu. Aikuiskasvatuksen 46. vuosikirja. Kansanvalistusseura ja Aikuiskasvatuksen tutkimusseura, 26-49.

Eteläpelto, A. \& Tynjälä, P. (1999). Johdanto. Teoksessa Eteläpelto, A. \& Tynjälä, P. (toim.) Oppiminen ja asiantuntijuus. Työelämän ja koulutuksen näkökulmia. Helsinki: WSOY, 10-23.

Eteläpelto, A. (1996). Asiantuntijuuden kehittyminen. Miten tullaan noviisista ekspertiksi? Teoksessa Sarkkinen, M. (toim.) Psykologia; Johdantokurssi. Jyväskylä: Gummerus, 48-63.

Forsseìn, T. (2005). Huumehoidon asiantuntijuuden rakentuminen päiväkeskuksessa. Sosiaali- ja terveysalan tutkimus- ja kehittämiskeskus. Raportteja; 1/2005. Helsinki: Stakes.

Hansson, H. (1998). Kollektiv kompetens: en studie av skicklig interaktiv handling. Lund: Studentlitteratur.

Howe, D. (1993). On being a client. Understanding the process of counselling and psychotherapy. Wiltshire: SAGE.

Isopahkala-Bouret, U. (2008). Asiantuntijuus kokemuksena. Aikuiskasvatus 28 (2), 84-93.

Isopahkala-Bouret, U. (2005). Joy and struggle for renewal: a narrative inquiry into expertise in job transitions. Helsingin yliopiston kasvatustieteen laitoksen tutkimuksia, 201. Helsinki: University of Helsinki.

Jokinen, A. \& Juhila, K. (2008) Jännitteitä ja suuntaviivoja aikuisten sosiaalityössä. Teoksessa Jokinen, A. \& Juhila, K. (toim.) Sosiaalityö aikuisten parissa. Tampere: Vastapaino, 282-289.

Juhila, K. (2006). Sosiaalityöntekijöinä ja asiakkaina. Sosiaalityön yhteiskunnalliset tehtävät ja paikat. Tampere: Vastapaino.

Juntunen, E. (2009). Valtaa diakoniasta? Valtautumisen monet merkitykset diakoniatyössä. Janus 17 (2), 139-155.

Juntunen, E. (2007). 'KKoska se on muutakin kuin osto-osoitus". Diakoniatyöntekijöiden motivaatio taloudelliseen auttamiseen. Diakonian tutkimuksen aikakauskirja 2/2007, 87-108.

Juntunen, E. (2006). Diakoniatyön taloudellinen apu ja viimesijaisen sosiaaliturvan aukot. Teoksessa Juntunen, E.; Grönlund, H. \& Hii- 
lamo, H.: Viimeisellä luukulla. Tutkimus viimesijaisten sosiaaliturvan aukoista ja diakoniatyön kohdentumisesta. Helsinki: Kirkkohallitus. 51-176.

Juntunen, Elina

\section{HAASTATTELUT}

21(H01-H21) diakoniantyöntekijän teemahaastattelua. 1.12.2005-28.2.2006.Aineisto tekijän hallussa.

\section{KYSELYT}

Diakoniatyöntekijöiden vastaukset kyselyyn, 22 vastausta (vastaaja 01 -vastaaja 22). Touko-kesäkuu 2008. Aineisto tekijän hallussa.

Karvinen, S. (1996). Sosiaalityön ammatillisuus modernista professionaalisuudesta reflektiiviseen asiantuntijuuteen. Kuopion yliopiston julkaisuja. E, Yhteiskuntatieteet; 34. Kuopio: Kuopion yliopisto.

Koivunen, N. \& Parviainen, J. (2004). Kollektiivinen asiantuntijuus - kymmenen kysymys$t a ̈$. Tutkijat Jaana Parviainen ja Niina Koivunen vastaavat. Tampereen yliopisto. Verkkodokumentti. http://www.uta.fi/tutkimus/liike/ seminaari030604/parviainen.pdf. 20.6.2009.

Kosonen, P.A. (2005). Sosiaalialan ja hoitotyön asiantuntijuuden kehitysehdot ja opiskelijavalinta. Jyväskylä studies in education, psychology and social research; 271. Jyväskylä: Jyväskylän yliopisto.

Kääriäinen, K.; Ketola, K.; Niemelä, K.; Palmu, H. \& Salomäki, H. (2008). Monikasvoinen kirkko. Suomen evankelis-luterilainen kirkko vuosina 2004-2007. Kirkon tutkimuskeskuksen julkaisuja 103. Tampere: Kirkon tutkimuskeskus.

Latvus, K., Manuksela A.M. \& Hyväri, S. (2005). Valottumismenetelmä diakoniatyössä. Teoksessa Hänninen, S., Karjalainen, J. \& Lahti, Tuukka (toim.) Toinen tieto. Kirjoituksia huono-osaisuuden tunnistamisesta. Helsinki: Stakes, 136-150.

Mieg, H.A. (2001). The social psychology of expertise. Case studies in research, professional domains, and expertise roles. Mahwah: Erlbaum.

Molander, G. (2003). Työtunteet-esimerkkinä vanhustyö. Jyväskylä: Gummerus.

Mäkeläinen, P. \& Mäkeläinen, V. (1999). Asiantuntijuus kuolevan potilaan hoidossa sai- raanhoitajien määrittelemänä. Pro Gradu tutkielma, hoitotieteen laitos. Kuopio: Kuopion Yliopisto.

Paajanen, T. (2008). Diakonia ja sosiaalityö kumppaneina sosiaalisen työn kentällä. Diakonia- ja sosiaalityöntekijöiden konstruoimana. Pro gradu-tutkielma, Sosiaalipolitiikan ja sosiaalityön laitos. Tampere: Tampereen yliopisto.

Parvianen, J. (2006). Kollektiivinen asiantuntijuus. Tampere: Tampere University Press.

Payne, M. (1996). What is Professional Social Work? Birmingham: Venture Press.

Pesonen, A. (2005). Asiantuntijuus ja osaaminen sosiaali- ja terveysalan mielenterveystyössä: pari-, tiimi-ja verkostotyö sekä muutos ja työssä jaksaminen. Diakonia-ammattikorkeakoulun julkaisuja. D, Työpapereita, 28. Helsinki: Diakonia ammattikorkeakoulu.

Pohjola, A. (2007). Merkintöjä sosiaalityön asiantuntijuudesta. Teoksessa Vesterinen, K. (toim.) Kiitos kysymyksestä. Pohjois-Suomen sosiaalialan osaamiskeskuksen julkaisusarja 27. Rovaniemi: Pohjois-Suomen sosiaalialan osaamiskeskus, 6-18.

Pyykkö, R. (2007). Yhdessä kirkon virassa? Diakoniatyön paikan määrittely kirkon virkarakennekeskustelussa. Diakonian tutkimuksen aikakauskirja 2/2007, 109-136.

Rauhala, L. (2005). Ihmiskäsitys ihmistyössä. Helsinki: Yliopistopaino.

Roivainen, I. (2008). Onko yhdyskuntatyö katoamassa suomalaisesta sosiaalityöstä? Teoksessa Roivanen, I; Nylund, M.; Korkiamäki, R. \& Raitakari S (toim.) Yhteisöt ja sosiaalityö. Kansalaisen vai asiakkaan asialla? Jyväskylä: PS-kustannus, 25-42.

Ruohotie, P. (2006). Metakognitiiviset taidot ja ammatillinen kasvu asiantuntijakoulutuksessa. Teoksessa Eteläpelto, A. \& Onnismaa, J. (toim.) Ammatillisuus ja ammatillinen kas$v u$. Aikuiskasvatuksen 46. vuosikirja. Kansanvalistusseura ja Aikuiskasvatuksen tutkimusseura. Kansanvalistusseura, 106-122.

Saarelainen, R.; Stengård, E. \& Vuori-Kemilä, A. (2002). Mielenterveys- ja päihdetyö: yhteistyötä ja kumppanuutta. Helsinki: WSOY.

Suhonen, K. (2009). Mitä hiljainen tieto on hengellisessä työssä? Kokemuksellinen näkö- 
kulma hiljaisen tiedon ilmenemiseen, siirrettävyyteen ja siirrettävyyden merkitykseen ikääntyneiden diakoniatyöntekijöiden ja pappien työssä. Jyväskylä studies in education, psychology and social research, 358. Jyväskylä: Jyväskylän yliopisto.

Tikkamäki, K. (2007). Tunnetyössä oppiminen. Tarkastelussa saattohoitajan työ. Aikuiskasvatus 27 (4), 256-265.

Tirri, K. (2003) Miten uskontoa opitaan? Teologinen Aikakauskirja 108 (2), 102-106.

Tynjälä, P. (1999). Oppiminen tiedon rakentamisena. Konstruktivistien oppimiskäsityksen perusteita. Helsinki: Tammi.

Valkeavaara, T. (1999). "Sailing in Calm Waters Doesn't Teach": Constructing expertise through problems in work - The case of Finnish human resource developers. Studies in Continuing Education 21 (2), 177-196.

Yeung, A.B. (2003). The Re-emergence of the Church in the Finish Public life? Christian Social Work as an Indicator of the Public Status of the Church. Journal of Contemporary Religion 2/2003, 197-211.

\section{Viitteet}

1. Diakoniatyön apu on tarkoitettu niille, joiden hätä on suurin eikä muuta apua ole saatavissa.

2. Summa ei sisällä rovastikuntien, hiippakuntien ja kirkon diakoniarahaston avustuksia.

3. Kaikki kirkon diakoniatyön virkaan pätevöityvät opiskelijat saavat diakonia-ammattikorkeakoulusta kaksoispätevyyden, joka merkitsee sitä, että opiskelija on valmistuttuaan samanaikaisesti pätevä sosionomi tai sairaanhoitaja. Kirkon tehtäviin vaadittavat teologiset ja kirkolliset opinnot määrittelee evankelis-luterilaisen kirkon piispainkokous, ja niiden laajuus on 90 opintopistettä. (Diakonia-ammattikorkeakoulu 2008. www.diak.fi.)

4. Kiitos Irene Roivaiselle, Heikki Hiilamolle ja refereille käsikirjoituksen kommentoinnista.

5. Sosiaalityön tutkimus toimii tässä artikkelissa keskustelukumppanina suhteessa diakoniatyön asiantuntijuuteen

6. Kirkon diakoniatyöntekijän ydinosaamisen keskiössä ovat ihmiset, diakoniatyön voimavarana ja kohteena (Diakoniatyöntekijöiden ydinosaamiskuvaus 30.3.2007).

7. Artikkelin perustana olevan aineiston keräsin Viimeisellä luukulla -tutkimukseen (Juntunen 2006), jossa kartoitin diakoniatyön taloudellista apua ja viimesijaisen sosiaaliturvan ongelmakohtia. Aiemmassa tutkimuksessa en selvittänyt diakoniatyöntekijöiden asiantuntijuutta.

8. Kirkon diakoniarahasto on Suomen evankelisluterilaisen kirkon yhteinen avustusrahasto, jonka tarkoituksena on avun antaminen taloudelliseen ahdinkoon joutuneille (Kirkon diakoniarahasto 9.4.2009).

9. Espoolaisesta diakoniatyöstä tekee mielenkiintoisen muun muassa se, että ihmisten muuttoliike ja alueelliset rakenteelliset muutokset heijastuvat suoraan myös diakoniatyön työtehtävien painotuksiin ja asiantuntijuuteen.

10. Karvinen viittaa tutkimuksessaan Olkin (1986) käyttämään käsitteeseen insturmentaalis-ratioaalinen pätevyysulottuvuus, joka tarkoittaa sitä, että sosiaalityöntekijä hallitsee tietyt välineelliset tiedot ja taidot sekä tuntee sosiaalityön periaatteet ja metodit (Karvinen 1996, 19).

11. Olen koodannut haastatellut diakoniatyöntekijät numerosarjalla H01-H21. Kyselyyn vastanneet olen koodannut sarjalla Vastaaja 1-Vastaaja 22. Käytän koodeja tuloslukujen haastattelujen ja kyselyn vastausten sitaateissa.

12. "Sosiaalinen luototus on sosiaalihuoltoon kuuluvaa luotonantoa, jonka tarkoituksena on ehkäistä taloudellista syrjäytymistä ja ylivelkaantumista sekä edistää henkilön ja perheen itsenäistä suoriutumista”. (Sosiaalinen luototus. Opas luototuksen käynnistäjälle. www.stm.fi/suomi/pao/sosluototus/osa1.htm. 20.11.2009)

13. Yhteisö- ja alueosaaminen sisältää evankelisluterilaisessa kirkossa toteutettavan yhdyskuntatyön.

Artikkeli saapui toimitukseen 29.7.2009.

Se hyväksyttiin julkaistavaksi toimituskunnan kokouksessa 20.1.2010. 